\title{
Thermodynamics of Some Simple Sulfur-Containing Molecules
}

\author{
William H. Evans and Donald D. Wagman
}

\begin{abstract}
The thermodynamic functions $\left(F^{\circ}-H_{0}^{\circ}\right) / T,\left(H^{\circ}-H_{0}^{\circ}\right) / T, S^{\circ}\left(H^{\circ}-H_{0}^{\circ}\right)$, and $C_{p}^{\circ}$ are calculated to high temperatures for gaseous sulfur (monatomic and diatomic), sulfur monoxide, sulfur dioxide, sulfur trioxide, and hydrogen sulfide from molecular and spectroscopic data. Values of the heats of formation of the various atomic and molecuiar species are selected from published experimental data, and certain industrially important equilibria are calculated.
\end{abstract}

\section{Introduction}

The calculation of the thermodynamic properties of a number of simple gaseous sulfur-containing molecules has been carried out as a part of the Bureau's program on the compilation of tables of Selected Values of Chemical Thermodynamic Properties. The data on a large number of inorganic sulfur compounds had been critically evaluated by K. K. Kelley in 1936 [1]. ${ }^{1}$ Since that date, sufficient new information has been reported in the literature to warrant a reevaluation and recalculation of the properties of gaseous monatomic and diatomic sulfur, sulfur monoxide, sulfur dioxide, sulfur trioxide, and hydrogen sulfide. ${ }^{2}$

The calculations are divided into two parts: (a) Calculation of the thermodynamic functions, $\left(F^{\circ}-H_{o}^{\circ}\right) / T,\left(H^{\circ}-H_{o}^{\circ}\right) / T, S^{\circ},\left(H^{\circ}-H_{o}^{\circ}\right)$, and $C_{p}^{\circ}$, for the various molecules in the ideal gaseous state; and (b) selection of "best" values for the heats of formation of the various compounds.

\section{Units}

The calorie used in these calculations is the thermochemical calorie, defined as 4.1840 abs j. The gas constant $R$ is taken as $1.98719 \mathrm{cal} / \mathrm{mole}{ }^{\circ} \mathrm{K}$. The atomic weights used are $\mathrm{H}, 1.0080 ; \mathrm{O}, 16.0000$; S, 32.066 [2]. The standard states chosen for the elements are $\mathrm{O}_{2}(\mathrm{~g}), \mathrm{H}_{2}(\mathrm{~g})$, both in the ideal gas state at 1-atm pressure, and $\mathrm{S}$ (c, rhombic). As is customary, nuclear spin and isotopic mixing contributions to the entropy and free-energy functions have been omitted.

\section{Calculation of the Thermodynamic Func- tions}

The translational contributions to the free-energy function. $\left(F^{\circ}-H_{0}^{\circ}\right) / T$; the heat-content function, $\left(H^{\circ}-H_{0}^{\circ}\right) / T$; entropy, $S^{\circ}$; and heat capacity, $C_{p}^{\circ}$, were calculated for all the molecules, using the equations given by Wagman et al. [3].

1 Figures in brackets indicate the literature references given at the end of this

paper.
2 The higher polymeric forms of sulfur, $\mathrm{S}_{4}, \mathrm{~S}_{6}$, and $\mathrm{S}_{8}$, are not included in this report. The necessary molecular data on $S_{4}$ and $S_{6}$ are not available; indeed the existence of $\mathrm{S}_{4}$, which has been assumed in the interpretation of the most recent existence of $\mathrm{S}_{4}$, which has been assumed in the interpretation of the most recent
gas density measurements [53], is still unproved. Dr. George Guthrie of the U. S. Bureau of Mines, Bartlesville, Okla., has recently completed calculations of the thermodynamic functions of gaseous $\mathrm{S}_{8}[54]$.
For monatomic sulfur gas the only other contribution is from the electronic excitation. The electronic functions were calculated by direct summation of the energy levels, using term values and multiplicities (table 1) from Moore [4] and the conversion factor $1 \mathrm{~cm}^{-1}=2.85851 \mathrm{cal} / \mathrm{mole}$. Only the five lowest levels are significant below $5,000^{\circ} \mathrm{K}$.

TABLE 1. Spectroscopic energy levels for $\mathrm{S}(\mathrm{g})$

\begin{tabular}{|c|c|c|}
\hline Term designation & Energy & $\begin{array}{l}\text { Multi- } \\
\text { plicity }\end{array}$ \\
\hline $\begin{array}{l}{ }^{3} \mathrm{P}_{2} \\
{ }_{3} \mathrm{P}_{1} \\
{ }_{3}^{3} \mathrm{P}_{0} \\
{ }_{1} \mathrm{D}_{2} \\
{ }_{1} \mathrm{~S}_{0}\end{array}$ & $\begin{array}{r}c m^{-1} \\
0.0 \\
396.8 \\
573.6 \\
9239.0 \\
22181.4\end{array}$ & $\begin{array}{l}5 \\
3 \\
1 \\
5 \\
1\end{array}$ \\
\hline
\end{tabular}

For diatomic sulfur gas the rotational and vibrational constants selected by Herzberg [5] for the isotopic $\mathrm{S}_{2}^{32}$ molecule were corrected to the naturally occurring isotopic mixture, using the relations given by Herzberg [6]:

$$
\sqrt{\frac{\mu}{\mu_{i}}}=\rho=\frac{\omega_{e_{i}}}{\omega_{e}} \text { and } x_{e_{i}} \omega_{e_{i}}=\rho^{2} x_{e} \omega_{e}
$$

where $\omega_{e}$ is the fundamental equilibrium vibrational frequency, $x_{e}$ the anharmonicity constant, and $\mu$ the reduced mass. These corrected values, $\omega_{e}=724.62$ $\mathrm{cm}^{-1}$ and $x_{e} \omega_{e}=2.844 \mathrm{~cm}^{-1}$, were used to calculate approximate thermodynamic functions, assuming a rigid rotator of symmetry number 2 and an independent harmonic oscillator of frequency $\omega_{e}-2 x_{e} \omega_{e}$. In the rigid rotator calculation the equations given by Wagman et al. [3] were used. The harmonic oscillator calculations were carried out, using the tables of the Planck-Einstein functions calculated by Johnston, Savedoff, and Belzer [7]. The triplet electronic ground state required the addition of $R \ln 3$ to the entropy and $-R \ln 3$ to the free-energy function.

Corrections for rotational stretching, vibrational anharmonicity, and rotational-vibrational interaction were calculated by using the second-order expansions given by Mayer and Mayer [8] at 300, 500, 1,000, 1,500 , and $2,000^{\circ} \mathrm{K}$; values at intermediate temperatures were obtained by graphical interpolation. At 
$1,500^{\circ} \mathrm{K}$ these corrections amounted to -0.03 $\mathrm{cal} / \mathrm{mole}{ }^{\circ} \mathrm{K}$ for the free-energy function, 0.04 for the heat-content function, and 0.09 for the heat capacity.

For sulfur monoxide gas the rotational and vibrational constants taken from Herzberg [5] were corrected for isotopic composition to give the constants $\omega_{e}=1123.09 \mathrm{~cm}^{-1}$ and $x_{e} \omega_{e}=6.109 \mathrm{~cm}^{-1}$, which were used in the rigid rotator-harmonic oscillator calculation. The triplet ground state required the addition of $R \ln 3$ to the entropy and $-R \ln 3$ to the free-energy function. Anharmonicity and stretching corrections were evaluated as for diatomic sulfur gas. At $1,500^{\circ} \mathrm{K}$ these corrections were $-0.02,0.02$, and $0.05 \mathrm{cal} / \mathrm{mole}{ }^{\circ} \mathrm{K}$ for the free-energy function, heat-content function, and heat capacity, respectively.

For sulfur dioxide gas, the product of the moments of inertia was taken as the average of the microwave measurements of Dailey, Golden, and Wilson [9], who obtained $106.403 \times 10^{-117} \mathrm{~g}^{3} \mathrm{~cm}^{6}$, Sirvetz [10], $107.007 \times 10^{-117} \mathrm{~g}^{3} \mathrm{~cm}^{6}$, and Crable and Smith [11], $106.996 \times 10^{-117} \mathrm{~g}^{3} \mathrm{~cm}^{6}$. This product of the moments of inertia, $106.80 \times 10^{-117} \mathrm{~g}^{3} \mathrm{~cm}^{6}$, and the vibrational frequencies given by Herzberg [12] were used in a rigid rotator-harmonic oscillator calculation. As the available data do not permit the calculation of the anharmonicities, these were estimated from the relation, based on the data for sulfur monoxide, $X_{i j}=0.003\left(\nu_{i}+\nu_{j}\right)$, where $X_{i j}$ is the anharmonicity arising from the interaction of the two fundamental frequencies $\nu_{i}$ and $\nu_{j}$ [13]. These were used to correct the rigid rotator-harmonic oscillator calculation by the method developed by Stockmayer, Kavanagh, and Mickley [13]. In this treatment the vibrational levels of a molecule with nondegenerate fundamental frequencies are taken as

$$
\frac{E_{v}-E_{0}}{h c}=\sum v_{i} v_{i}-\sum_{i} X_{i i}\left(v_{i}-1\right)-\sum_{i<j} X_{i j} v_{i} v_{j},
$$

where $\nu_{i}$ are the observed fundamentals, in $\mathrm{cm}^{-1}, v_{i}$ are quantum numbers, and $X_{i i}$ are the anharmonicities, in $\mathrm{cm}^{-1}$, as calculated above. If the anharmonicities are considered to be small, their contribution to the Eoltzmann factor can be expanded and the vibrational partition function $Q_{v}$ readily summed:

$$
Q_{v}=\Pi_{i}\left[1-e^{-u_{i}}\right]^{-1}\left[1+\sum_{i \leq j} f_{i j}+\ldots\right],
$$

where

$$
\begin{aligned}
& u_{i}=h c \nu_{i} / k T \\
& f_{i i}=2 X_{i i} h c\left[k T\left(e^{u_{i}-1}\right)^{2}\right]^{-1} \\
& f_{i j}=X_{i j} h c\left[k T\left(e^{u_{i}}-1\right)\left(e^{u_{j}}-1\right)\right]^{-1} .
\end{aligned}
$$

This expression is equivalent to $Q^{\prime}{ }_{v} Q_{c}$, where $Q^{\prime}{ }_{v}$ is the partition function for a barmonic oscillator with frequencies $\nu_{i}$, and $Q_{c}$ is the partition function containing the anharmonicities. $Q_{c}$ may then be written as

$$
Q_{c}=1+\sum_{i \leq j} f_{i j}
$$

From this the correction to the free-energy function is given by $-F_{c} / T=R \ln Q_{c}$. Differentiation with respect to $\dot{T}$ gives the corrections to the heat-content function, $H_{c} / T=R T\left(d \ln Q_{c} / d T\right)$, and the heat capacity, $C_{c}=R d\left(T^{2} d \ln Q_{c} / d T\right) / d T$. In this way corrections to the free energy function, heat content function, and heat capacity (amounting to $-0.05,0.10$, and $0.23 \mathrm{cal} / \mathrm{mole}^{\circ} \mathrm{K}$ at $1,500^{\circ} \mathrm{K}$, respectively,) were calculated at $300^{\circ}, 500^{\circ}, 1,000^{\circ}$, and $1,500^{\circ} \mathrm{K}$; intermediate values were interpolated graphically.

The value $59.29 \mathrm{cal} / \mathrm{mole}^{\circ} \mathrm{K}$ for the entropy at $298.16^{\circ} \mathrm{K}$ may be compared with $59.24 \pm 0.10$ [14] obtained from the low-temperature calorimetric data of Giauque and Stephenson [15].

In the case of sulfur trioxide gas, the recent calculations of Stockmayer, Kavanagh, and Mickley [13] were checked and converted to the values of the fundamental constants used in this paper.

For hydrogen sulfide gas, the rigid rotator-harmonic oscillator calculations and corrections, made in the same way as for sulfur dioxide, were based upon the recent complete vibrational analysis of Allen, Cross, and King [16], which gives the anharmonicity terms. Moments of inertia were taken from the work of Allen, Cross, and Wilson [17], Grady, Cross, and King [18], and Hainer and King [19] and corrected to approximate equilibrium values by comparison with water vapor. These gave a product $I_{x} I_{y} I_{z}$ equal to $49.25 \times 10^{-120} \mathrm{~g}^{3} \mathrm{~cm}^{6}$. A stretching correction, insignificant in the case of the other polyatomic molecules, was applied by using the method of Wilson [20]. The corrections to the rigid rotator-harmonic oscillator at $1,500{ }^{\circ} \mathrm{K}$ were $-0.06,0.08$, and $0.22 \mathrm{cal} / \mathrm{mole}{ }^{\circ} \mathrm{K}$ for the free-energy function, heat-content function, and heat capacity.

The calculated value of the entropy at $298.16^{\circ} \mathrm{K}$, $49.17 \mathrm{cal} / \mathrm{mole}^{\circ} \mathrm{K}$, may be compared with the value [14] $49.11 \pm 0.10$ obtained from the low-temperature calorimetric data of Clusius and Frank [21] and Giauque and Blue [22[.

To correct values of $\Delta I f^{\circ}$ and $\Delta F f^{\circ}$ between $0^{\circ} \mathrm{K}$ and $298.16^{\circ} \mathrm{K}$, it was necessary to know the ther-

\begin{tabular}{|c|c|c|}
\hline & $298.16^{\circ} \mathrm{K}$ & $300^{\circ} \mathrm{K}$ \\
\hline & $\begin{array}{c}\mathrm{cal} / \mathrm{mole} \\
K\end{array}$ & $\underset{K}{c a l / m o l e}$ \\
\hline$\left(F^{\circ}-H_{0}^{\circ}\right) / T_{\ldots} \ldots$ & -4.086 & -4.097 \\
\hline$\left(H^{\circ}-H_{0}^{\circ}\right) / T_{\ldots} \ldots$ & 3.532 & 3.544 \\
\hline$C_{p}^{\circ} \ldots$ & 5.401 & 5.412 \\
\hline
\end{tabular}
modynamic functions at the latter temperature for crystalline rhombic sulfur. These were obtained by graphical integration of the heat capacity data of Eastman and McGavock [23] as follows:

TABLE 2. Thermodynamic functions for $\mathrm{S}$ (c, rhombic)

\section{Selection of the "Best" Values for the Heats of Formation}

The heat of formation of sulfur dioxide gas is based upon the combustion measurements of Eckman and Rossini [24], who burned excess sulfur in 
oxygen under conditions precluding the formation of sulfur trioxide. Their data, when corrected for the atomic weight of sulfur, give for the selected value:

$$
\begin{gathered}
\mathrm{S}(\mathrm{c}, \text { rhombic })+\mathrm{O}_{2}(\mathrm{~g})=\mathrm{SO}_{2}(\mathrm{~g}) \\
\Delta H_{298.16}^{\circ}=-70.947 \pm 0.050 \mathrm{kcal} / \mathrm{mole}^{3}
\end{gathered}
$$

The earlier combustion measurements at constant pressure of Thomsen [26], which yield $\Delta H_{298.16}^{\circ}=$ $-71.04 \pm 0.50 \mathrm{kcal} / \mathrm{mole}$, confirm this value. Berthelot $[27,28]$, in two sets of combustions at constant volume using two different analytical techniques, obtained $\Delta H_{298.16}^{\circ}=-69.46 \pm 1.00 \mathrm{kcal} / \mathrm{mole}$. The data of Giran [29], who obtained heats of combustion at various high oxygen pressures, give $\Delta H_{298,16}^{\circ}=$ $-70.5 \pm 0.8 \mathrm{kcal} / \mathrm{mole}$.

The value for the heat of formation of hydrogen sulfide gas is based upon: (a) the heat of combustion of hydrogen sulfide gas obtained by Zeumer and Roth [30] and by Thomsen [26], together with the value for the heat of formation of $\mathrm{SO}_{2}(\mathrm{~g})$ selected above and that for water given by Rossini et al. [25]; (b) the heat of reaction of $\mathrm{H}_{2} \mathrm{~S}(\mathrm{~g})$ with a solution of iodine in aqueous hydriodic acid [26], combined with the appropriate values of the heats of formation given in Rossini et al.; and (c), the heat of reaction derived from the equilibrium measurements of Pollitzer [31] on the reaction of $\mathrm{H}_{2} \mathrm{~S}(\mathrm{~g})$ with crystalline iodine to give hydrogen iodide gas and rhombic sulfur, together with the heat of formation of $\mathrm{HI}(\mathrm{g})$ given by Rossini et al. These results, as summarized in table 3 , lead to

$$
\mathrm{S}(\mathrm{c}, \text { rhombic })+\mathrm{H}_{2}(\mathrm{~g})=\mathrm{H}_{2} \mathrm{~S}(\mathrm{~g})
$$

\begin{tabular}{|c|c|c|}
\hline Observer & Method & $\Delta H f_{298.16}^{\circ}$ \\
\hline $\begin{array}{l}\text { Thomsen [26] } \\
\text { Thomsen [26] } \\
\text { Pollitzer [31] } \\
\text { Zeumer and Roth [30] }\end{array}$ & $\begin{array}{l}\text { Combustion of } \mathrm{H}_{2} \mathrm{~S} \\
\text { Reaction w ith } \mathrm{H}-\mathrm{I}_{2} \\
\text { (aqueous). } \\
\text { Reaction with } \mathrm{I}_{2} \text { (c) } \\
\text { Combustion of } \mathrm{H}_{2} \mathrm{~S}\end{array}$ & $\begin{array}{c}\mathrm{kcal} / \mathrm{mole} \\
\mathrm{a}-2.61 \pm 0.50 \\
-4.82 \pm 0.20 \\
-4.81 \pm 0.20 \\
-4.82 \pm 0.14\end{array}$ \\
\hline
\end{tabular}

$\Delta H_{298,16}^{\circ}=-4.82 \pm 0.10 \mathrm{kcal} / \mathrm{mole}$.

TABLE 3. Heat of formation of $\mathrm{H}_{2} \mathrm{~S}(\mathrm{~g})$

a Omitted in obtaining "best" value.

For sulfur trioxide several sets of high-temperature measurements of the equilibrium between sulfur dioxide, sulfur trioxide, and oxygen are available. These were combined with the appropriate freeenergy functions [32] and the heat of formation of sulfur dioxide to calculate the values of $\Delta H_{0}^{\circ}$ for the reaction

$$
2 \mathrm{SO}_{2}(\mathrm{~g})+\mathrm{O}_{2}(\mathrm{~g})=2 \mathrm{SO}_{3}(\mathrm{~g})
$$

and $\Delta H f_{298,16}^{\circ}$ for sulfur trioxide gas given in table 4 .

A value of $-94.35 \pm 0.12 \mathrm{kcal} / \mathrm{mole}$ for the heat of formation of sulfur trioxide gas was obtained from

\begin{tabular}{|c|c|c|c|}
\hline Observer & $\begin{array}{l}\text { Num- } \\
\text { ber } \\
\text { of } \\
\text { meas- } \\
\text { ure- } \\
\text { ments }\end{array}$ & $\Delta H_{0}^{\circ}$ & $\Delta H f_{298.16}^{\circ} \mathrm{SO}_{3}(\mathrm{~g})$ \\
\hline $\begin{array}{l}\text { Bodländer and Koppen [33] } \\
\text { Knietsch [34] } \\
\text { Lunge and Reinhardt [35] } \\
\text { Bodenstein and Pohl [36] } \\
\text { Lucas [37] } \\
\text { Taylor and Lenher [40] } \\
\text { Kapustinskiľ and Shamov- } \\
\quad \text { skiǔ }[38,39]\end{array}$ & $\begin{array}{r}6 \\
11 \\
39 \\
49 \\
7 \\
4 \\
\\
11\end{array}$ & $\begin{array}{c}k c a l \\
-46.28 \pm 0.36 \\
-44.23 \pm 0.50 \\
-45.25 \pm 0.25 \\
-45.57 \pm 0.04 \\
-49.33 \pm 0.65 \\
-45.45 \pm 0.10 \\
-45.57 \pm 0.08\end{array}$ & $\begin{aligned} k c a l & \\
-94.87 & \pm 0.60 \\
-93.84 & \pm 0.80 \\
-94.36 & \pm 0.20 \\
-94.52 & \pm 0.01 \\
-96.40 & \pm 1.40 \\
-94.46 & \pm 0.12 \\
-94.52 & \pm 0.07\end{aligned}$ \\
\hline
\end{tabular}

\footnotetext{
3 The uncertainties in $\Delta H$ given in this section of the paper represent the present writers' best estimates of the overall uncertainties in the values.
}

TABLE 4. Heats of dissociation of $\mathrm{SO}_{3}(\mathrm{~g})^{\text {a }}$

a The uncertainties given for $\Delta H_{0}^{\circ}$ represent the probable error of the mean of the measurements. Those given for $\Delta I f^{\circ}{ }_{288.16}$, as elsewhere in this paper, are the the measurements. Those given
estimated over-all uncertainties.

calorimetric measurements of Roth and coworkers [41-43] through a series of reactions involving the heat of solution of liquid sulfur trioxide in water [42], the heat of solution of gaseous sulfur dioxide in aqueous hydrogen peroxide [41], the heat of decomposition of hydrogen peroxide [41], the heat of dilution of sulfuric acid [25,42], and the heat of vaporization of sulfur trioxide [25].

As the best value a weighted average was taken to give

$$
\begin{gathered}
\mathrm{S}(\mathrm{c}, \text { rhombic })+3 / 2 \mathrm{O}_{2}(\mathrm{~g})=\mathrm{SO}_{3}(\mathrm{~g}) \\
\Delta H_{298.16}^{\circ}=-94.47 \pm 0.07 \mathrm{kcal} .
\end{gathered}
$$

Because of the complex polymerization in sulfur vapor below $1,000^{\circ} \mathrm{K}[1,53]$, the best value for the heat of formation of diatomic sulfur gas is obtained from measurements of dissociation of hydrogen sulfide at high temperatures, where sulfur exists primarily as $\mathrm{S}_{2}$. Three series of such measurements are available [44, 45, 46]. All were carried out by determining the pressure of the hydrogen formed by the dissociation of hydrogen sulfide, using a platinum membrane. In addition, Preuner and Schupp [45] measured the increase in total pressure of a small sample of $\mathrm{H}_{2} \mathrm{~S}$ when heated in a sealed bulb; these results give a $\Delta H_{0}^{\circ}$ differing less than 0.02 keal from the over-all average. Combination of the equilibrium constants calculated from these meas-

\begin{tabular}{|c|c|c|}
\hline Observer & $\begin{array}{l}\text { Number of } \\
\text { measure- } \\
\text { ments }\end{array}$ & $\Delta H_{0}^{\circ}$ a \\
\hline $\begin{array}{l}\text { Preuner [44] } \\
\text { Preuner and Schupp }[45] \\
\text { Randall and Bichowsky }[46]\end{array}$ & $\begin{array}{r}5 \\
20 \\
4\end{array}$ & $\begin{array}{c}k c a l \\
19.506 \pm 0.040 \\
19.528 \pm 0.031 \\
19.557 \pm 0.044\end{array}$ \\
\hline
\end{tabular}
urements with the appropriate free-energy functions [32] gives the values for the heat of dissociation

$$
\mathrm{H}_{2} \mathrm{~S}(\mathrm{~g})=\mathrm{H}_{2}(\mathrm{~g})+1 / 2 \mathrm{~S}_{2}(\mathrm{~g})
$$

tabulated in table 5 .

TABle 5. Heat of dissociation of $\mathrm{H}_{2} \mathrm{~S}$

a The uncertainties given for $\Delta H_{0}^{\circ}$ represent the probable error of the mean of the measurements. 
The weighted average $19.53 \pm 0.02 \mathrm{kcal}$, the heat of formation of hydrogen sulfide selected previously, and the appropriate heat-content functions [32] give the heat of formation of diatomic sulfur gas:

$$
\begin{gathered}
2 \mathrm{~S}(\mathrm{c}, \text { rhombic })=\mathrm{S}_{2}(\mathrm{~g}) \\
\Delta H^{\circ}{ }_{298.16}=30.84 \pm 0.15 \mathrm{kcal} .
\end{gathered}
$$

The best value for the heat of formation of monatomic sulfur gas appears to be that derived from spectroscopic studies. From a study of predissociation, Olsson [47] selected a value of 3.6 electron volts (ev) as an upper limit for the dissociation energy of diatomic sulfur gas into normal ${ }^{3} \mathrm{P}$ sulfur atoms. ${ }^{4}$ Considering all such data and by comparison with molecules of similar structure Goldfinger, Juenehomme and Rosen [48] selected $4.41 \mathrm{ev}$ for the dissociation into one normal ${ }^{3} \mathrm{P}$ atom and one excited ${ }^{1} \mathrm{D}$ atom. Herzberg [5] favored a value of 3.6 ev or lower for the dissociation into normal atoms, and Gaydon [49], after summarizing the evidence, assumed that the value of $4.41 \mathrm{ev}$ from predissociation measurements corresponds to the true dissociation energy. If the value $4.41 \mathrm{ev}$ is selected as dissociation into one normal atom and one excited ${ }^{1} \mathrm{D}$ atom, as favored by Herzberg, then the dissociation energy is

$$
\begin{gathered}
\mathrm{S}_{2}(\mathrm{~g})=2 \mathrm{~S}\left({ }^{3} \mathrm{P}\right)(\mathrm{g}) \\
\Delta H_{0}^{\circ}=75.3 \pm 0.5 \mathrm{kcal} .{ }^{5}
\end{gathered}
$$

Partial confirmation of this lower value is furnished by high-temperature gas-density measurements. Nernst [50], using the Victor-Meyer method at 1,900 to $2,300{ }^{\circ} \mathrm{K}$, obtained $71 \pm 8$ kcal for $\Delta H_{0}^{\circ}$; von Wartenberg [51] in the same way obtained $75 \pm$ $10 \mathrm{kcal}$. Using the spectroscopic value of $\Delta H_{0}^{\circ}$ and the value for diatomic sulfur gas,

$$
\begin{gathered}
\mathrm{S}(\mathrm{e}, \text { rhombic })=\mathrm{S}(\mathrm{g}) \\
\Delta H_{298.16}^{\circ}=53.54 \quad \pm 0.50 \quad \mathrm{kcal} .
\end{gathered}
$$

Additional confirmation is afforded by measurements of Bjerrum [52] on the heat of dissociation of hydrogen sulfide gas at 2,900 to $3,200^{\circ} \mathrm{K}$. For the dissociation to monatomic sulfur and diatomic hydrogen gases he found $\Delta H_{0}^{\circ}=51 \pm 15 \mathrm{kcal}$, which leads to a value of $\Delta H f_{298.16}^{\circ}$ for $\mathrm{S}(\mathrm{g})$ of $56 \pm 15 \mathrm{kcal}$.

The spectroscopic data on sulfur monoxide gas do not lead to a definite value for the dissociation of the molecule because of the uncertainty in the energy states of the dissociation products. Herzberg [5] favors dissociation into $\mathrm{S}\left({ }^{1} \mathrm{D}\right)+\mathrm{O}\left({ }^{3} \mathrm{P}\right)$, which leads to a dissociation energy of $4.001 \mathrm{ev}$. Gaydon [49] assumes dissociation to $\mathrm{S}\left({ }^{1} \mathrm{P}\right)+\mathrm{O}\left({ }^{1} \mathrm{P}\right)$, with a dissociation energy greater by the difference $\mathrm{S}\left({ }^{1} \mathrm{D}\right)-\mathrm{S}\left({ }^{3} \mathrm{P}\right)$, or $5.146 \mathrm{ev}$. (Dissociation into the third simple combination of products, $\mathrm{S}\left({ }^{3} \mathrm{P}\right)+\mathrm{O}\left({ }^{1} \mathrm{D}\right)$, appears unlikely because of the greater energy differences in-

\footnotetext{
${ }_{4} 1 \mathrm{ev} / \mathrm{molecule}=23060.5 \mathrm{cal} / \mathrm{mole}$.

5 Since this report was written measurements of the heat of formation of HS (g) by Franklin and Lumpkin [55] and of the dissociation energy $\mathrm{D}_{0}$ for $\mathrm{HS}$ by Porter [56] indicate that the higher value of $4.41 \mathrm{ev}$ for $\mathrm{D}_{0}$ of $\mathrm{S}_{2}$ is probably the correct value. If this value is accepted, the values of $\Delta H f^{\circ}$ and $\Delta F f^{\circ}$ for $\mathrm{S}(\mathrm{g})$ will be
and increased by $13.2 \mathrm{kcal}$. with corresponding changes in $\log _{10} K f$.
}

volved.) The lower value was selected because the dissociation is apparently of the same type as that of $\mathrm{S}_{2}$ and $\mathrm{O}_{2}$. Combining this value with the values for gaseous atomic sulfur and oxygen [25], the heat of formation of sulfur monoxide is calculated

$$
\begin{gathered}
\mathrm{S}(\mathrm{c}, \text { rhombic })+1 / 2 \mathrm{O}_{2}(\mathrm{~g})=\mathrm{SO}(\mathrm{g}) \\
\Delta H_{298.16}^{\circ}=19.30 \pm 0.50 \mathrm{kcal}^{6}{ }^{6}
\end{gathered}
$$

In order to extend the useful range of the data on the reactions of formation, the values of $\Delta H f^{\circ}$ selected above were converted to values based on $\mathrm{S}_{2}(\mathrm{~g})$ as the standard reference state for sulfur. The values of the heat of formation, $\Delta H f^{\circ}$; free energy of formation, $\Delta F f^{\circ}$; and logarithm of the equilibrium constant of formation, $\log _{10} K f$, were then calculated at temperatures up to $1,500^{\circ} \mathrm{K}$ by the relations

$$
\begin{gathered}
\Delta H f_{T}^{\circ}=\Delta H f_{0}^{\circ}+\Delta\left(H_{T}^{\circ}-H_{0}^{\circ}\right) \\
\Delta F f_{T}^{\circ}=\Delta H f_{0}^{\circ}+T \Delta\left[\left(F^{\circ}-H_{0}^{\circ}\right) / T\right] \\
\log _{10} K f=-\left(\Delta F f_{T}^{\circ} / 4.57567 T\right) .
\end{gathered}
$$

The values calculated in this manner, as well as the thermodynamic functions for the six gaseous molecules considered, are given in tables 6 to 12 .

As examples of the applications of these tables, three industrially important reactions were considered. Figure 1 shows the equilibrium composition obtained when gaseous hydrogen sulfide decomposes

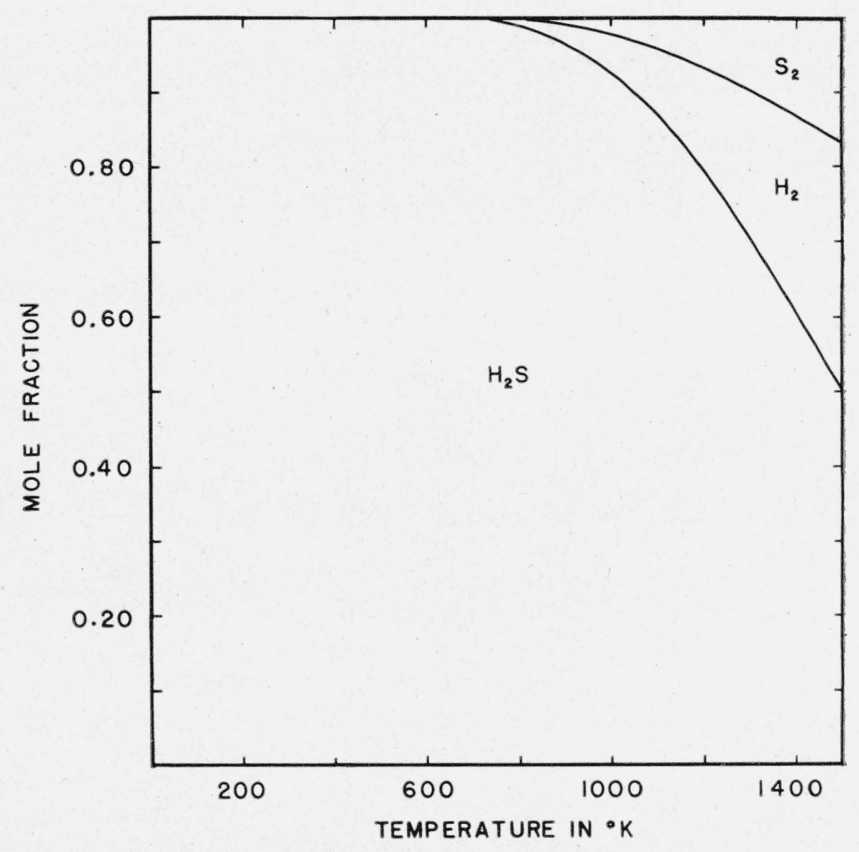

FIgURE 1. Equilibrium composition for a $2 \mathrm{H}_{2}: \mathrm{S}_{2}$ mixture at 1-atmosphere pressure as a function of temperature.

The vertical width of a band represents the mole fraction of the component present.

${ }^{6}$ As indicated in footnote 5 , the best value of $D_{0}\left(S_{2}\right)$ appears to be $4.41 \mathrm{ev}$. By reasoning as above, the higher value of $5.146 \mathrm{ev}$ appears more likely for $\mathrm{D}_{0}$ of SO. If this value is accepted, as well as $4.41 \mathrm{ev}$ for $\mathrm{D}_{0}$ of $\mathrm{S}_{2}$, the values of $\Delta H f^{\circ}$ and $\Delta F f^{\circ}$ for SO $\mathrm{Sg}$ ) will become more negative by $13.2 \mathrm{keal}$, with corresponding changes in $\log _{10} K f$. 
under a total pressure of $1 \mathrm{~atm}$. The ordinate gives the mole fraction of each component; the abscissa the absolute temperature. The equilibrium composition was obtained by first calculating the equilibrium constant for the reaction

$$
\mathrm{H}_{2} \mathrm{~S}(\mathrm{~g})=\mathrm{H}_{2}(\mathrm{~g})+1 / 2 \mathrm{~S}_{2}(\mathrm{~g})
$$

at various temperatures, using the relation

$$
-4.57567 \log _{10} K=\Delta F_{T}^{\circ} / T
$$

and the values of the free energies of formation given in the present paper and in Rossini et al. [32]. The values of $K$ were then used to obtain the equilibrium composition in the usual way. The side reactions

$$
\begin{aligned}
\mathrm{S}_{2}(\mathrm{~g}) & =2 \mathrm{~S}(\mathrm{~g}) \\
\mathrm{H}_{2}(\mathrm{~g}) & =2 \mathrm{H}(\mathrm{g}) \\
\mathrm{H}_{2} \mathrm{~S}(\mathrm{~g}) & =\mathrm{HS}(\mathrm{g})+\mathrm{H}(\mathrm{g}) \\
2 \mathrm{~S}_{2}(\mathrm{~g}) & =\mathrm{S}_{4}(\mathrm{~g}) .^{7}
\end{aligned}
$$

were also considered. After the values for $\mathrm{H}_{2}$ and $\mathrm{S}_{2}$ were obtained, they were used to calculate the concentrations of the other possible products; in no case were the side reactions significant.

Figure 2 shows the equilibrium composition obtained in the gaseous decomposition of sulfur trioxide

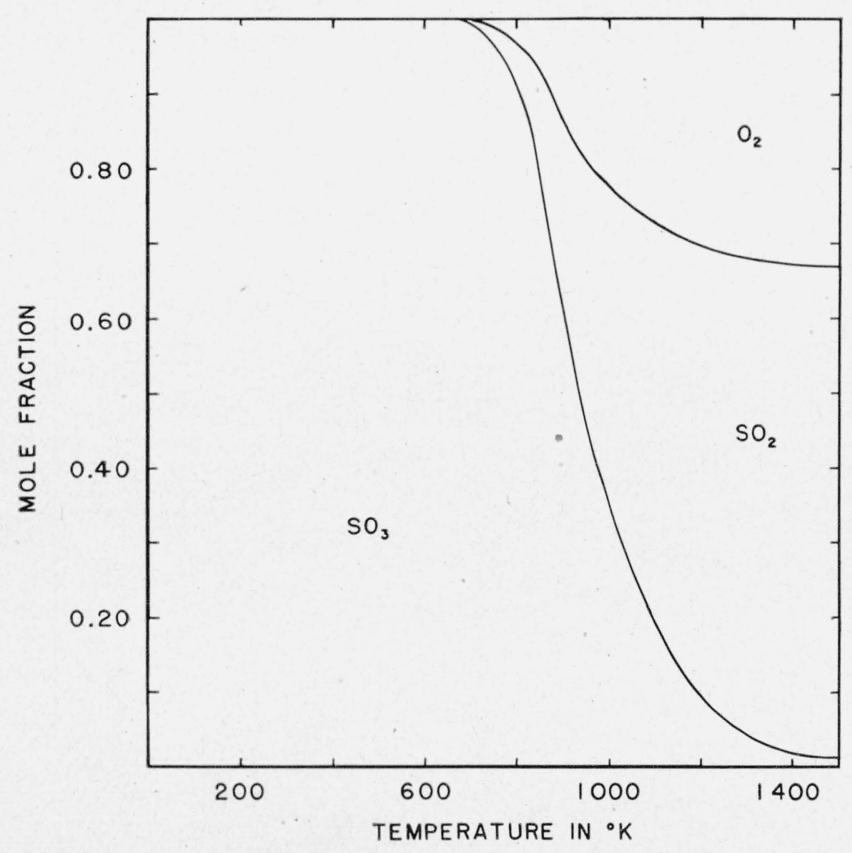

FIGURE 2. Equilibrium composition for a $3 \mathrm{O}_{2}: \mathrm{S}_{2}$ mixture at 1-atmosphere pressure as a function of temperature.

The vertical width of a band represents the mole fraction of the component present.

${ }^{7}$ For the calculation of the equilibrium compositions of the various sulfur species the data of Braune, Peter, and Neveling [53] were used. at a total pressure of $1 \mathrm{~atm}$. Possible side reactions considered were

$$
\begin{gathered}
\mathrm{SO}_{2}(\mathrm{~g})=\mathrm{SO}(\mathrm{g})+1 / 2 \mathrm{O}_{2}(\mathrm{~g}) \\
2 \mathrm{SO}_{2}(\mathrm{~g})=\mathrm{S}_{2}(\mathrm{~g})+2 \mathrm{O}_{2}(\mathrm{~g}) \\
\mathrm{SO}_{3}(\mathrm{~g})=\mathrm{SO}_{2}(\mathrm{~g})+\mathrm{O}(\mathrm{g})
\end{gathered}
$$

all were unimportant.

Figure 3 shows the equilibrium composition of the vapor obtained from mixing two molecular volumes of hydrogen sulfide and one of sulfur dioxide at a total final pressure of $1 \mathrm{~atm}$. At temperatures below about $500^{\circ} \mathrm{K}$ liquid sulfur separates [1] with a corresponding increase in the concentration of the water vapor. Side reactions considered, in addition to those listed above, were

$$
\begin{aligned}
3 \mathrm{~S}_{2}(\mathrm{~g}) & =\mathrm{S}_{6}(\mathrm{~g}) \\
4 \mathrm{~S}_{2}(\mathrm{~g}) & =\mathrm{S}_{8}(\mathrm{~g}) \\
\mathrm{H}_{2} \mathrm{O}(\mathrm{g}) & =\mathrm{OH}(\mathrm{g})+\mathrm{H}(\mathrm{g}) .
\end{aligned}
$$

Of these, only the sulfur polymerization was significant; for this, the results of Braune, Peter, and Noveling [53] were used, although their data are not completely satisfactory. These results indicate that recovery of sulfur from hydrogen sulfide gas by partial oxidation should be feasible.

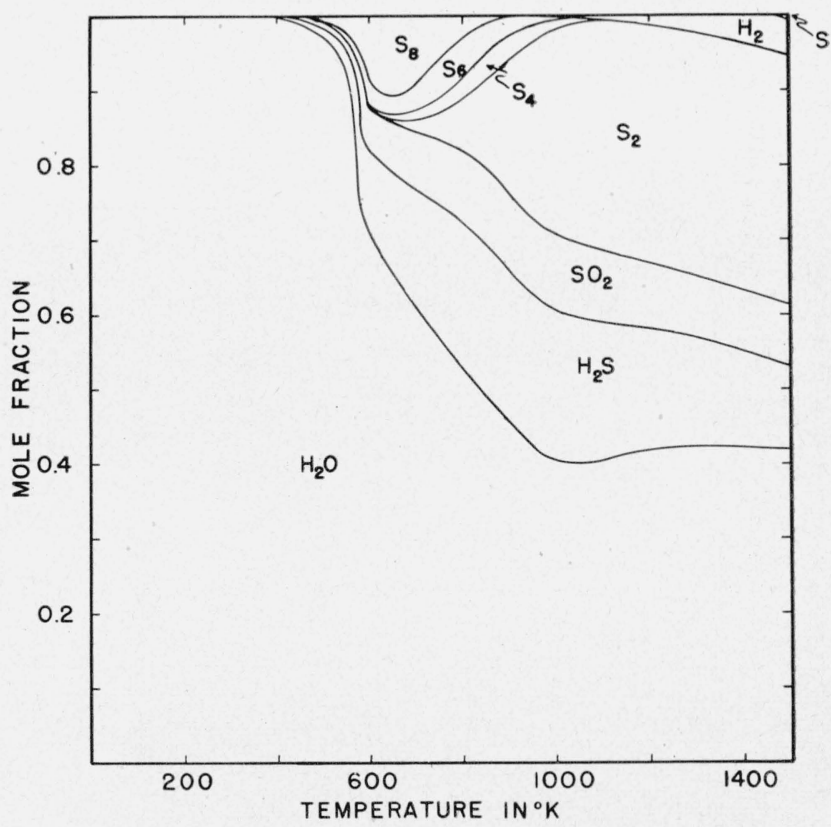

FIGURE 3. Equilibrium composition for a $2 \mathrm{H}_{2} \mathrm{~S}_{\mathrm{SO}} \mathrm{SO}_{2}$ mixture at 1-atmosphere pressure as a function of temperature.

The vertical width of a band represents the mole fraction of the component present. 


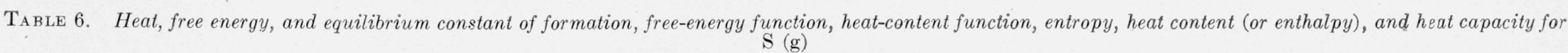

Reference states for elements, used for calculating $\Delta H f^{\circ}, \Delta F f^{\circ}$, and $\log K f: \mathrm{S}_{2}$ (g).

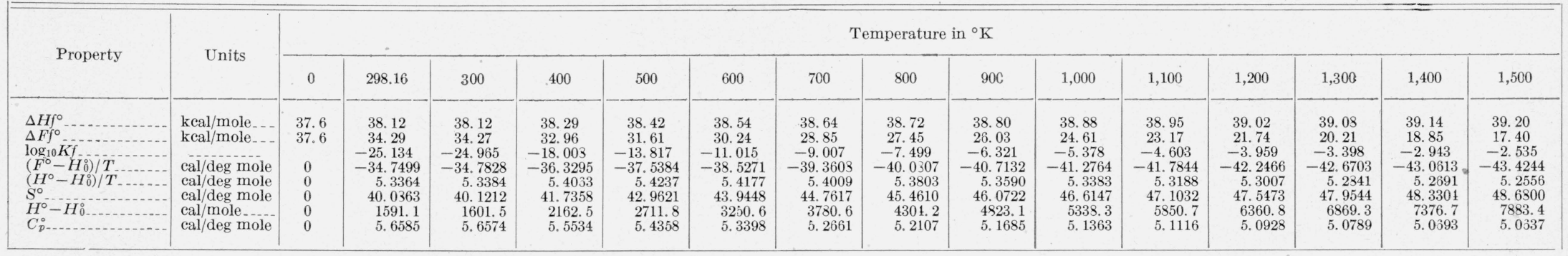

TABLE 7. Free-energy function, heat-content function, entropy, heat content (or enthalpy), and heat capacity for $\mathrm{S}$ (g)

\begin{tabular}{|c|c|c|c|c|c|c|c|c|c|c|c|}
\hline \multirow{2}{*}{ Property } & \multirow{2}{*}{ Units } & \multicolumn{10}{|c|}{ Temperature in ${ }^{\circ} \mathrm{K}$} \\
\hline & & 1,600 & 1,700 & 1,800 & 1,900 & 2,000 & 2,100 & 2,200 & 2,300 & 2,400 & 2,500 \\
\hline $\begin{array}{l}\left(F^{\circ}-H_{0}^{\circ}\right) / T \\
\left(H^{\circ}-H_{0}^{\circ}\right) / \mathrm{T} \\
S^{\circ} \\
H^{\circ}-H_{0}^{\circ} \\
C_{p}^{\circ}\end{array}$ & $\begin{array}{l}\mathrm{cal} / \mathrm{deg} \text { mole } \\
\mathrm{cal} / \mathrm{deg} \text { mole- } \\
\mathrm{cal} / \mathrm{deg} \text { mole- } \\
\mathrm{cal} / \mathrm{mole} \text {-..-- } \\
\mathrm{cal} / \mathrm{deg} \text { mole_ }\end{array}$ & $\begin{array}{r}-43.7631 \\
5.2435 \\
49.0066 \\
8389.6 \\
5.0618\end{array}$ & $\begin{array}{r}-44.0806 \\
5.2328 \\
49.3134 \\
8895.8 \\
5.0632\end{array}$ & $\begin{array}{r}-44.3795 \\
5.2235 \\
49.6030 \\
9402.3 \\
5.0678\end{array}$ & $\begin{array}{r}-44.6617 \\
5.2155 \\
49.8772 \\
9909.4 \\
5.0752\end{array}$ & $\begin{array}{r}-44.9290 \\
5.2087 \\
50.1377 \\
10417.4 \\
5.0852\end{array}$ & $\begin{array}{r}-45.1830 \\
5.2031 \\
50.3861 \\
10926.5 \\
5.0974\end{array}$ & $\begin{array}{r}-45.4249 \\
5.1986 \\
50.6235 \\
11436.9 \\
5.1115\end{array}$ & $\begin{array}{r}-45.6560 \\
5.1951 \\
50.8511 \\
11948.7 \\
5.1272\end{array}$ & $\begin{array}{r}-45.8770 \\
5.1927 \\
51.0697 \\
12462.5 \\
5.1442\end{array}$ & $\begin{array}{r}-46.0889 \\
5.1911 \\
51.2800 \\
12977.8 \\
5.1623\end{array}$ \\
\hline Property & Units & 2,750 & 3,000 & 3,250 & 3,500 & 3,750 & 4,000 & 4,250 & 4,500 & 4,750 & 5,000 \\
\hline $\begin{array}{l}\left(F^{\circ}-H_{0}^{\circ}\right) / T \\
\left(H^{\circ}-H_{0}^{\circ}\right) / T^{\prime} \\
S^{\circ} \\
H^{\circ}-H_{0}^{\circ} \\
C_{p}^{\circ}\end{array}$ & $\begin{array}{l}\mathrm{cal} / \mathrm{deg} \text { mole_- } \\
\mathrm{cal} / \mathrm{deg} \text { mole- } \\
\mathrm{cal} / \mathrm{deg} \text { mole- } \\
\mathrm{cal} / \mathrm{mole} \text { - } \\
\mathrm{cal} / \mathrm{deg} \text { mole_- }\end{array}$ & $\begin{array}{r}-46.5837 \\
5.1906 \\
51.7743 \\
14274.2 \\
5.2098\end{array}$ & $\begin{array}{r}-47.0354 \\
5.1943 \\
52.2297 \\
15582.9 \\
5.2581\end{array}$ & $\begin{array}{r}-47.4514 \\
5.2010 \\
52.6524 \\
16903.2 \\
5.3045\end{array}$ & $\begin{array}{r}-47.8371 \\
5.2099 \\
53.0470 \\
18234.6 \\
5.3472\end{array}$ & $\begin{array}{r}-48.1970 \\
5.2201 \\
53.4174 \\
19576.5 \\
5.3854\end{array}$ & $\begin{array}{r}-48.5343 \\
5.2318 \\
53.7661 \\
20927.2 \\
5.4185\end{array}$ & $\begin{array}{r}-48.8518 \\
5.2436 \\
54.0354 \\
22285.3 \\
5.4464\end{array}$ & $\begin{array}{r}-49.1518 \\
5.2555 \\
54.4073 \\
23649.8 \\
5.4694\end{array}$ & $\begin{array}{r}-49.4363 \\
5.2673 \\
54.7036 \\
25019.7 \\
5.4878\end{array}$ & $\begin{array}{r}-49.7038 \\
5.2787 \\
54.9855 \\
26393.5 \\
5.5021\end{array}$ \\
\hline
\end{tabular}

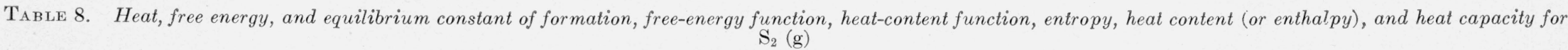

Reference states for elements, used for calculating $\Delta H f^{\circ}, \Delta F f^{\circ}$, and $\log K f: \mathrm{S}_{2}(\mathrm{~g})$

\begin{tabular}{|c|c|c|c|c|c|c|c|c|c|c|c|c|c|c|c|c|}
\hline \multirow{2}{*}{ Property } & \multirow{2}{*}{ Units } & \multicolumn{15}{|c|}{ Temperature in ${ }^{\circ} \mathrm{K}$} \\
\hline & & 0 & 298.16 & 300 & 400 & 500 & 600 & 700 & 800 & 900 & 1,000 & 1,100 & 1,200 & 1,300 & 1,400 & 1,500 \\
\hline $\begin{array}{l}\Delta H f^{\circ} \\
\Delta F f^{\circ} \\
\log _{10} \bar{K} f \\
\left(F^{\circ}-H_{0}^{\circ} / / T\right. \\
H^{\circ}-H_{0}^{\circ} / T^{\circ} \\
S^{\circ} H^{\circ}-H_{0}^{\circ} \\
C_{p}^{\circ}-\end{array}$ & $\begin{array}{l}\mathrm{kcal} / \mathrm{mole} . . \\
\mathrm{kcal} / \mathrm{mole} \\
\text { cal/deg mole- } \\
\text { cal/deg mole- } \\
\text { cal/deg mole } \\
\text { cal/mole } \\
\text { cal/deg mole }\end{array}$ & $\begin{array}{l}0 \\
0 \\
0 \\
0 \\
0 \\
0 \\
0\end{array}$ & \begin{tabular}{r}
\multicolumn{1}{c}{0} \\
0 \\
0 \\
-47.33 \\
7.18 \\
54.51 \\
2141 \\
7.76
\end{tabular} & $\begin{array}{r}0 \\
0 \\
0 \\
-47.37 \\
7.18 \\
54.55 \\
2154 \\
7.77\end{array}$ & $\begin{array}{r}0 \\
0 \\
0 \\
-49.47 \\
7.38 \\
56.85 \\
2952 \\
8.14\end{array}$ & $\begin{array}{r}0 \\
0 \\
0 \\
-51.13 \\
7.56 \\
58.69 \\
3780 \\
8.39\end{array}$ & $\begin{array}{r}0 \\
0 \\
0 \\
-52.52 \\
7.71 \\
60.23 \\
4626 \\
8.54\end{array}$ & $\begin{array}{r}0 \\
0 \\
0 \\
-53.72 \\
7.84 \\
61.56 \\
5488 \\
8.65\end{array}$ & $\begin{array}{r}0 \\
0 \\
0 \\
-54.78 \\
7.95 \\
62.73 \\
6360 \\
8.73\end{array}$ & $\begin{array}{r}0 \\
0 \\
0 \\
-55.72 \\
8.04 \\
63.76 \\
7236 \\
8.79\end{array}$ & $\begin{array}{r}0 \\
0 \\
0 \\
-56.57 \\
8.11 \\
64.68 \\
8110 \\
8.84\end{array}$ & $\begin{array}{r}0 \\
0 \\
0 \\
0 \\
-57.34 \\
8.18 \\
65.52 \\
8998 \\
8.87\end{array}$ & $\begin{array}{r}0 \\
0 \\
0 \\
-58.06 \\
8.24 \\
66.30 \\
9888 \\
8.90\end{array}$ & $\begin{array}{r}0 \\
0 \\
0 \\
-58.72 \\
8.29 \\
67.01 \\
10777 \\
8.92\end{array}$ & $\begin{array}{r}0 \\
0 \\
0 \\
0 \\
-59.34 \\
8.34 \\
67.68 \\
11676 \\
8.94\end{array}$ & $\begin{array}{r}0 \\
0 \\
0 \\
-59.92 \\
8.38 \\
68.30 \\
12570 \\
8.96\end{array}$ \\
\hline
\end{tabular}




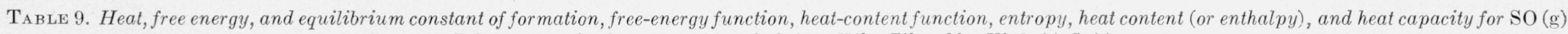
Reference states for elements, used for calculating $\Delta H f^{\circ}, \Delta F f^{\circ}$, and $\log K f: \mathrm{O}_{2}(\mathrm{~g}) ; \mathrm{S}_{2}(\mathrm{~g})$.

\begin{tabular}{|c|c|c|c|c|c|c|c|c|c|c|c|c|c|c|c|c|}
\hline \multirow{2}{*}{ Property } & \multirow{2}{*}{ Units } & \multicolumn{15}{|c|}{ Temperature in ${ }^{\circ} \mathrm{K}$} \\
\hline & & 0 & 298.16 & 300 & 400 & 500 & 600 & 700 & 800 & 900 & 1,000 & 1,100 & 1,200 & 1,300 & 1,400 & 1,500 \\
\hline $\begin{array}{l}\Delta I I f^{\circ} \\
\Delta F f^{\circ} \\
\log _{10} \bar{K} f^{\circ} \\
\left(F^{\circ}-H_{0}^{\circ}\right) / T \\
\left(H^{\circ}-H_{0}^{\circ}\right) / T \\
S^{\circ} \\
H^{\circ}-H_{0}^{\circ} \\
C_{p}^{\circ}\end{array}$ & $\begin{array}{l}\mathrm{kcal} / \mathrm{mole} \\
\mathrm{kcal} / \mathrm{mole} \\
\mathrm{cal} / \mathrm{deg} \text { mole } \\
\text { cal/deg mole } \\
\text { cal/deg mole } \\
\text { cal/mole. } \\
\text { cal/deg mole }\end{array}$ & $\begin{array}{l}3.9 \\
3.9 \\
\\
0 \\
0 \\
0 \\
0 \\
0\end{array}$ & $\begin{array}{c}3.88 \\
3.49 \\
-2.558 \\
-46.07 \\
7.01 \\
53.03 \\
2030 \\
7.23\end{array}$ & $\begin{array}{r}3.88 \\
3.49 \\
-2.542 \\
-46.10 \\
7.01 \\
53.11 \\
2103 \\
7.24\end{array}$ & $\begin{array}{c}3.87 \\
3.36 \\
-1.836 \\
-48.13 \\
7.11 \\
55.24 \\
2344 \\
7.57\end{array}$ & $\begin{array}{c}3.86 \\
3.24 \\
-1.416 \\
-49.73 \\
7.23 \\
56.96 \\
3615 \\
7.87\end{array}$ & $\begin{array}{c}3.86 \\
3.11 \\
-1.133 \\
-51.03 \\
7.36 \\
58.42 \\
4416 \\
8.11\end{array}$ & $\begin{array}{c}3.86 \\
2.99 \\
-0.934 \\
-52.20 \\
7.48 \\
59.68 \\
5236 \\
8.29\end{array}$ & $\begin{array}{c}3.87 \\
2.87 \\
-0.784 \\
-53.20 \\
7.59 \\
60.79 \\
6072 \\
8.42\end{array}$ & $\begin{array}{c}3.87 \\
2.74 \\
-0.665 \\
-54.10 \\
7.69 \\
61.79 \\
6921 \\
8.52\end{array}$ & $\begin{array}{c}3.87 \\
2.61 \\
-0.570 \\
-54.92 \\
7.77 \\
62.69 \\
7770 \\
8.60\end{array}$ & $\begin{array}{c}3.87 \\
2.48 \\
-0.493 \\
-55.67 \\
7.85 \\
63.52 \\
8635 \\
8.66\end{array}$ & $\begin{array}{c}3.87 \\
2.35 \\
-0.428 \\
-56.36 \\
7.92 \\
64.28 \\
9504 \\
8.71\end{array}$ & $\begin{array}{c}3.87 \\
2.23 \\
-0.375 \\
-56.99 \\
7.98 \\
64.97 \\
10374 \\
8.75\end{array}$ & $\begin{array}{c}3.87 \\
2.11 \\
-0.329 \\
-57.58 \\
8.01 \\
65.62 \\
11256 \\
8.79\end{array}$ & $\begin{array}{c}3.86 \\
1.99 \\
-0.290 \\
-58.14 \\
8.09 \\
66.23 \\
12135 \\
8.82\end{array}$ \\
\hline
\end{tabular}

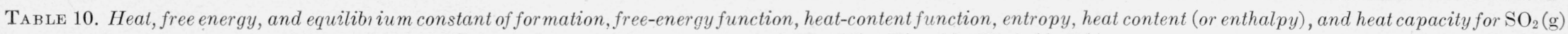
Reference states for elements, used for calculating $\Delta H f^{\circ}, \Delta F f^{\circ}$, and $\log K f: \mathrm{O}_{2}(\mathrm{~g}) ; \mathrm{S}_{2}(\mathrm{~g})$.

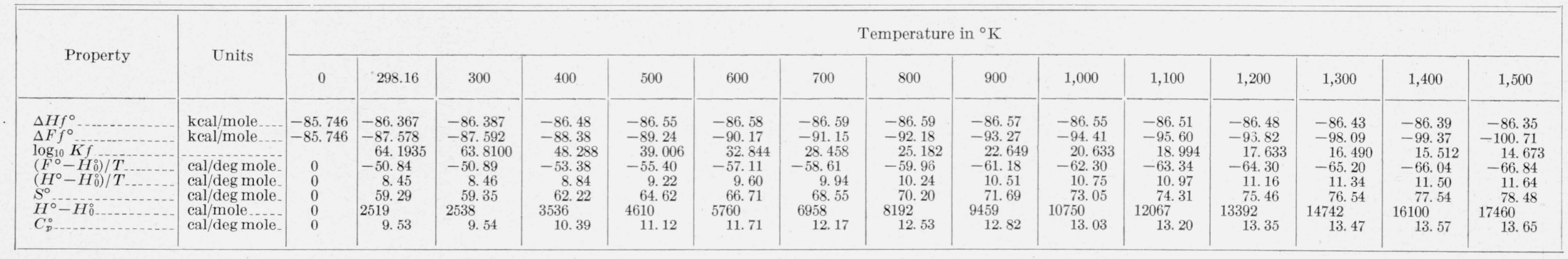

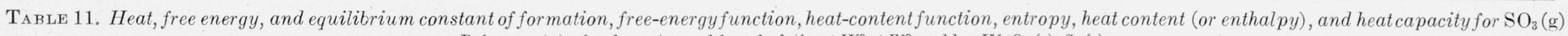
Reference states for elements, used for calculating $\Delta H f^{\circ}, \Delta F f^{\circ}$, and $\log K f: \mathrm{O}_{2}(\mathrm{~g}) ; \mathrm{S}_{2}(\mathrm{~g})$.

\begin{tabular}{|c|c|c|c|c|c|c|c|c|c|c|c|c|c|c|c|c|}
\hline \multirow{2}{*}{ Property } & \multirow{2}{*}{ Units } & \multicolumn{15}{|c|}{ Temperature in ${ }^{\circ} \mathrm{K}$} \\
\hline & & 0 & 298.16 & 300 & 400 & 500 & 600 & $7 \mathrm{CO}$ & 800 & 900 & 1,000 & 1,100 & 1,200 & 1,300 & 1,400 & 1,500 \\
\hline $\begin{array}{l}\Delta H f^{\circ} \\
\Delta F f^{\circ} \\
\log _{10} K f \\
\left(F^{\circ}-H_{0}^{\circ}\right) / T \\
\left(H^{\circ}-H_{0}^{\circ}\right) / T \\
S^{\circ} \\
H^{\circ}-H_{0}^{\circ} \\
C_{p}^{\circ}\end{array}$ & $\begin{array}{l}\mathrm{kcal} / \mathrm{mole} \\
\mathrm{kcal} / \mathrm{mole} \\
\text { cal/deg mole- } \\
\text { cal/deg mole- } \\
\text { cal/deg mole- } \\
\text { cal/mole...- } \\
\text { cal/deg mole- }\end{array}$ & $\begin{array}{c}-108.49 \\
-108.49 \\
0 \\
0 \\
0 \\
0 \\
0\end{array}$ & $\begin{array}{c}-109.89 \\
-98.09 \\
71.899 \\
-51.89 \\
9.30 \\
61.19 \\
273 \\
12.10\end{array}$ & $\begin{array}{c}-109.89 \\
-98.02 \\
71.407 \\
-51.95 \\
9.32 \\
61.27 \\
2796 \\
12.13\end{array}$ & $\begin{array}{c}-110.05 \\
-94.03 \\
51.375 \\
-54.76 \\
10.25 \\
65.01 \\
4100 \\
14.06\end{array}$ & $\begin{array}{c}-110.08 \\
-90.02 \\
39.347 \\
-57.14 \\
11.18 \\
68.32 \\
5590 \\
15.66\end{array}$ & $\begin{array}{c}-110.00 \\
-86.02 \\
31.332 \\
-59.26 \\
12.04 \\
71.30 \\
7224 \\
16.90\end{array}$ & $\begin{array}{c}-109.86 \\
-82.04 \\
25.614 \\
-61.18 \\
12.80 \\
73.98 \\
8960 \\
17.86\end{array}$ & $\begin{array}{c}-109.67 \\
-78.08 \\
21.330 \\
-62.94 \\
13.48 \\
76.42 \\
10784 \\
18.61\end{array}$ & $\begin{array}{c}-109.44 \\
-74.15 \\
18.006 \\
-64.57 \\
14.08 \\
78.65 \\
12672 \\
19.23\end{array}$ & $\begin{array}{c}-109.16 \\
-70.24 \\
15.351 \\
-66.08 \\
14.63 \\
80.71 \\
14630 \\
19.76\end{array}$ & $\begin{array}{c}-108.86 \\
-66.37 \\
13.186 \\
-67.50 \\
15.12 \\
82.62 \\
16632 \\
20.21\end{array}$ & $\begin{array}{c}-108.54 \\
-62.51 \\
11.384 \\
-68.83 \\
15.56 \\
84.39 \\
1872 \\
20.61\end{array}$ & $\begin{array}{c}-108.19 \\
-58.68 \\
9.865 \\
-70.09 \\
15.96 \\
86.05 \\
20748 \\
20.96\end{array}$ & $\begin{array}{c}-107.82 \\
-54.87 \\
8.565 \\
-71.28 \\
16.33 \\
87.61 \\
22862 \\
21.28\end{array}$ & $\begin{array}{c}-107.43 \\
-51.08 \\
7.442 \\
-72.40 \\
16.67 \\
89.07 \\
25005 \\
21.58\end{array}$ \\
\hline
\end{tabular}

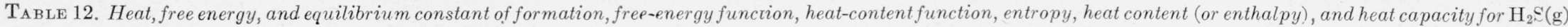
Reference states for elements, used for calculating $\Delta H f^{\circ}, \Delta F f^{\circ}$, and $\log K f: \mathrm{H}_{2}(\mathrm{~g}) ; \mathrm{S}_{2}(\mathrm{~g})$.

\begin{tabular}{|c|c|c|c|c|c|c|c|c|c|c|c|c|c|c|c|c|}
\hline \multirow{2}{*}{ Property } & \multirow{2}{*}{ Units } & \multicolumn{15}{|c|}{ Temperature in ${ }^{\circ} \mathrm{K}$} \\
\hline & & 0 & 298.16 & 300 & 400 & 500 & 600 & 700 & 800 & 900 & 1,000 & 1,100 & $1,20 \mathrm{C}$ & 1,300 & 1,400 & 1,500 \\
\hline $\begin{array}{l}\Delta H f^{\circ} \\
\Delta F f^{\circ} \\
\log _{10} K f \\
\left(F^{\circ}-H_{0}^{\circ} T\right. \\
\left.H^{\circ}-H_{0}^{\circ}\right) / T \\
H^{\circ}-H_{0}^{\circ} \\
C_{p}^{\circ}-H^{\circ}\end{array}$ & $\begin{array}{l}\text { kcal/mole- } \\
\text { kcal/mole-_ele } \\
\text { cal/deg mole- } \\
\text { cal/deg mole- } \\
\text { cal/deg mole- } \\
\text { cal/mole_.-. } \\
\text { cal/deg mole_ }\end{array}$ & $\begin{array}{c}-19.53 \\
-19.53 \\
0 \\
0 \\
0 \\
0 \\
0\end{array}$ & $\begin{array}{c}-20.24 \\
-17.47 \\
12.805 \\
-41.17 \\
8.00 \\
49.17 \\
2385 \\
8.19\end{array}$ & $\begin{array}{c}-20.24 \\
-17.45 \\
12.712 \\
-41.21 \\
8.00 \\
49.21 \\
2400 \\
8.20\end{array}$ & $\begin{array}{c}-20.50 \\
-16.48 \\
9.004 \\
-43.52 \\
8.09 \\
51.61 \\
3236 \\
8.53\end{array}$ & $\begin{array}{c}-20.74 \\
-15.44 \\
6.749 \\
-45.34 \\
8.21 \\
53.55 \\
4105 \\
48.93\end{array}$ & $\begin{array}{c}-20.95 \\
-14.36 \\
5.231 \\
-46.85 \\
8.37 \\
55.22 \\
5022 \\
9.35\end{array}$ & $\begin{array}{c}-21.13 \\
-13.25 \\
4.137 \\
-48.15 \\
8.54 \\
56.69 \\
5978 \\
9.78\end{array}$ & $\begin{array}{c}-21.27 \\
-12.11 \\
3.308 \\
-49.31 \\
8.72 \\
58.03 \\
6976 \\
10.21\end{array}$ & $\begin{array}{c}-21.38 \\
-10.97 \\
2.664 \\
-50.35 \\
8.91 \\
59.26 \\
8019 \\
10.62\end{array}$ & $\begin{array}{c}-21.45 \\
-9.80 \\
2.142 \\
-51.29 \\
9.10 \\
60.39 \\
9100 \\
11.00\end{array}$ & $\begin{array}{c}-21.50 \\
-8.64 \\
1.717 \\
-52.17 \\
9.29 \\
61.46 \\
10219 \\
11.34\end{array}$ & $\begin{array}{c}-21.54 \\
-7.47 \\
1.360 \\
-52.99 \\
9.47 \\
62.46 \\
11364 \\
11.64\end{array}$ & $\begin{array}{c}-21.55 \\
-6.29 \\
1.057 \\
-53.75 \\
9.65 \\
63.40 \\
12545 \\
11.92\end{array}$ & $\begin{array}{c}-21.55 \\
-5.11 \\
0.798 \\
-54.47 \\
9.82 \\
64.29 \\
13748 \\
12.16\end{array}$ & $\begin{array}{c}-21.54 \\
-3.94 \\
0.574 \\
-55.16 \\
9.98 \\
65.14 \\
14970 \\
12.37\end{array}$ \\
\hline
\end{tabular}




\section{References}

[1] K. K. Kelley, Contributions to the data on theoretical metallurgy. [VII] The thermodynamic properties of sulfur and its inorganic compounds, U. S. Bur. Mines Bul. 406 (1936).

[2] E. Wichers, J. Am. Chem. Soc. 72, 1431 (1950).

[3] D. D. Wagman, J. E. Kilpatrick, W. J. Taylor, K. S. Pitzer, and F. D. Rossini, J. Research NBS 34, 143 (1945) RP1634.

[4] C. E. Moore, Atomic energy levels, [I] NBS Circular 467 (U. S. Government Printing Office, Washington, D. C., 1949).

[5] G. Herzberg, Molecular spectra and molecular structure. [I] Spectra of diatomic molecules, 2d ed., 499-581 (D. Van Nostrand Co., New York, N. Y., 1950).

[6] See pages 141 to 144 of [5].

[7] H. L. Johnston, L. Savedoff, and J. Belzer, Contributions to the thermodynamic functions by a Planck-Einstein oscillator in one degree of freedom (Office of Naval Research, Washington, D. C., 1949).

[8] J. E. Mayer and M. G. Mayer, Statistical mechanics, p. 160-166 (John Wiley \& Sons, New York, N. Y., 1940).

[9] B. P. Dailey, S. Golden, and E. B. Wilson, Jr., Phys. Rev. 72, 871 (1951).

[10] M. H. Sirvetz, J. Chem. Phys. 19, 938 (1951).

[11] G. F. Crable and W. V. Smith, J. Chem. Phys. 19, 502 (1951).

[12] G. Herzberg, Molecular spectra and molecular structure. [II] Infrared and Raman spectra of polyatomic molecules (D. Van Nostrand Co., New York, N. Y., 1945).

[13] W. H. Stockmayer, G. M. Kavanagh, and H. S. Mickley, J. Chem. Phys. 12, 408 (1944).

[14] K. K. Kelley, Contributions to the data on theoretical metallurgy. [XI] Entropies of inorganic substances. Revision (1948) of data and methods of calculation, U. S. Bur. Mines Bul. 47\% (1950).

[15] W. F. Giauque and C. C. Stephenson, J. Am. Chem. Soc. 60, 1389 (1938)

[16] H. C. Allen, Jr., P. C. Cross, and G. W. King, J. Chem. Phys. 18, 1412 (1950).

[17] H. C. Allen, Jr., P. C. Cross, and M. K. Wilson, J. Chem. Phys. 18, 691 (1950).

[18] H. S. Grady, P. C. Cross, and G. W. King, Phys. Rev. 75, 1450 (1949).

[19] R. M. Hainer and G. W. King, J. Chem. Phys. 15, 89 (1947).

[20] E. B. Wilson, Jr., J. Chem. Phys. 4, 526 (1936).

[21] K. Clusius and A. Frank, Z. physik. Chem. B34, 420 (1936).

[22] W. F. Giauque and R. W. Blue, J. Am. Chem. Soc. 58, 831 (1936).

[23] E. D. Eastman and W. C. McGavock, J. Am. Chem. Soc. 59, 145 (1937).

[24] J. R. Eckman and F. D. Rossini, BS J. Research 3, 597 (1929) RP111.
[25] F. D. Rossini, D. D. Wagman, W. H. Evans, S. Levine, and I. Jaffe, Selected values of chemical thermodynamic properties, NBS Circular 500 (U. S. Government Printing Office, Washington, D. C., 1952).

[26] J. Thomsen, Thermochemische Untersuchungen, I-IV, (Barth, Leipzig, 1882-1886).

[27] M. Berthelot, Ann. chim. phys. [5] 13, 1 (1878).

[28] M. Berthelot, Ann. chim. phys. [5] 22, 422 (1881).

[29] H. Giran, Compt. rend. 139, 1219 (1904).

[30] H. Zeumer and W. A. Roth, Z. Elektrochem, 40, 777 (1934).

[31] F. Pollitzer, Z. anorg. Chem. 64, 121 (1909).

[32] Thermodynamic functions for $\mathrm{O}_{2}$ and $\mathrm{H}_{2}$ were taken from Series III tables of the NBS tables of selected values of chemical thermodynamic properties.

[33] G. Bodländer and K. Koppen. Z. Elektrochem. 9, 787 (1903).

[34] R. Knietsch, Ber. V Kong. angew. Chem. I, 614 (1903).

[35] G. Lunge and K. Reinhardt, Z. angew. Chem. 31, 1041 (1904).

[36] M. Bodenstein and W. Pohl, Z. Elektrochem. 11, 373 (1905).

[37] R. Lucas, Z. Elektrochem. 11, 457 (1905).

[38] A. F. Kapustinskił and L. Shamovskið̌, Acta Physicochim. U. R. S. S. 4, 791 (1936).

[39] A. F. KapustinskiY and L. ShamovskiY, Trudy Vsesoyuz. Nauch. Issled vatel'. Inst. Mineral'. Syr'ya. No. 109 55 (1936).

[40] G. B. Taylor and S. Lenher, Z. physik. Chem. Bodenstein-Festband, 30 (1931)

[41] W. A. Roth, R. Grau, and A. Meichsner, Zे. anorg. Chem. 193, 161 (1930).

[42] R. Grau and W. A. Roth, Z. anorg. Chem. 186, 173 (1930).

[43] R. Grau and W. A. Roth, Z. anorg. Chem. 186, 186 (1930)

[44] G. Preuner, Z. anorg. Chem. 55, 279 (1907).

[45] G. Preuner and W. Schupp, Z. physik. Chem. 68, 157 (1910).

[46] M. Randall and F. R. Bichowsky, J. Am. Chem. Soc. 40, 368 (1918).

[47] E. Olsson, Z. Physik 100, 656 (1936).

[48] P. Goldfinger, W. Jeunehomme, and B. Rosen, Nature 138, 205 (1936).

[49] A. G. Gaydon, Dissociation energies and spectra of diatomic molecules, p. 194-196 (Chapman and Hall, London, 1947).

[50] W. Nernst, Z. Elektrochem. 9, 622 (1903).

[51] H. von Wartenberg, Z. anorg. Chem. 56, 320 (1908).

$[52]$ N. Bjerrum, Z. physik. Chem. 81, 281 (1912).

[53] H. Braune, S. Peter, and V. Neveling, Z. Naturforsch. 6a, 32 (1951).

[54] Private communication from Dr. George Guthrie, Jr.

[55] J. L. Franklin and H. E. Lumpkin, J. Am. Chem. Soc. \%4, 1023 (1952).

[56] G. Porter, Discussions Faraday Soc. No. 9, 60 (1950).

Washington, May 14, 1952. 